\title{
Influence of competitive advantage on competitive positioning of Silesian companies in 2019
}

\author{
Olaf Flak ${ }^{1, *}$ and Grzegorz Głód ${ }^{2}$ \\ ${ }^{1}$ University of Silesia in Katowice, ul. Bankowa 12, 40-007 Katowice, Poland \\ ${ }^{2}$ University of Economics in Katowice, ul. 1 Maja 50, 40-287 Katowice, Poland
}

\begin{abstract}
Company competitiveness is still an important issue in management studies. It can be measured in several ways including competitive advantage and competitive positioning. The aim of the paper is to present the result of the annual research on company competitiveness conducted in Poland. The research question in this paper is: is there a relation between a certain type of competitive advantage and characteristics of a company competitive positioning? In the paper there is a description of the influence of competitive advantage on competitive positioning in six dimensions. Respondents in the research answered 45 questions in online survey at sensorium24.com (Company Competitiveness Barometer). 8 of the questions concerned the competitive advantage and 6 concerned the competitive positioning. There are a theoretical background of company competitiveness and phenomena which belongs to this general term - a competitive advantage and a competitive positioning, a methodology of research and results as well as conclusions.
\end{abstract}

\section{Introduction}

Competitive advantage and competitive positioning are used to describe an ability of a company to compete with one another. Dynamic and unexpected environment of a business needs from companies to be ready to use innovative and efficient competitive strategy in order to build a competitive advantage in the market [1]. Than the achieved competitive advantage influences on a competitive positioning which a company can be describe in terms of its profitability [2]. All of these phenomena belongs to a general term describing an ability of a company to compete on a market [3].

The aim of the paper is to present the result of the annual research on company competitiveness conducted in Poland. This project is called Company Competitiveness Barometer and its last edition was conducted form 09.01.2020 to 09.04.2020. Respondents from a few market sectors answered 45 questions in online survey at sensorium24.com. 8 of the questions concerned the competitive advantage and 6 concerned the competitive positioning. The research question in this paper is: is there a relation between a certain type of competitive advantage and characteristics of a company competitive positioning?

\footnotetext{
*Corresponding author: olaf.flak@us.edu.pl
} 
Section 2 contains a theoretical background of company competitiveness and phenomena which belongs to this general term - a competitive advantage and a competitive positioning. Section 3 describes a methodology of research. The results were presented in Section 4 and in Section 5 there are conclusions.

\section{Theoretical background of company competitiveness}

Company competitiveness is defined in many ways which depend on the perspective of main factor of competition on a certain market. A wide overview of the approaches to this issue led to design the Company Competitiveness Integrated Model in which there are 5 elements influencing a strength of a company on a market.

Firstly, the source of any actions is a competitive potential. This means any resources, which the company has or should have to be able to use them to build, maintain and strengthen its competitiveness. Secondly, the way of the use of the competitive potential is a competitive strategy which is an adopted program of action aiming to achieve a competitive advantage [4]. Thirdly, the effect of the competitive strategy is a competitive advantage defined as the ability of the company to deliver the tangible and intangible assets to the buyer through the market [5]. The fourth element is a competitive positioning, understood as the synthetic economic results of the company, resulting from the ability of the enterprise to compete now and in the future [6]. The last element of the Company Competitiveness Integrated Model is an environment of a company. It is called the platform of competition and means a set of macro- and microenvironmental features in which the company operates in the sector [7].

Authors after a few years of company competitiveness research formulated their own definition of the company competitiveness which covers all these five elements of the Company Competitive Integrated Model. Competitiveness can be understood as "an multidimensional attribute of the company, resulting from both the internal features and the ability to cope with external circumstances. Competitiveness is relative, that means, there is no absolute scale for measuring competitiveness, (...) competitiveness can be used to describe the mutual relations of enterprises in the market." [5] The Company Competitiveness Integrated Model is shown in Fig. 1.

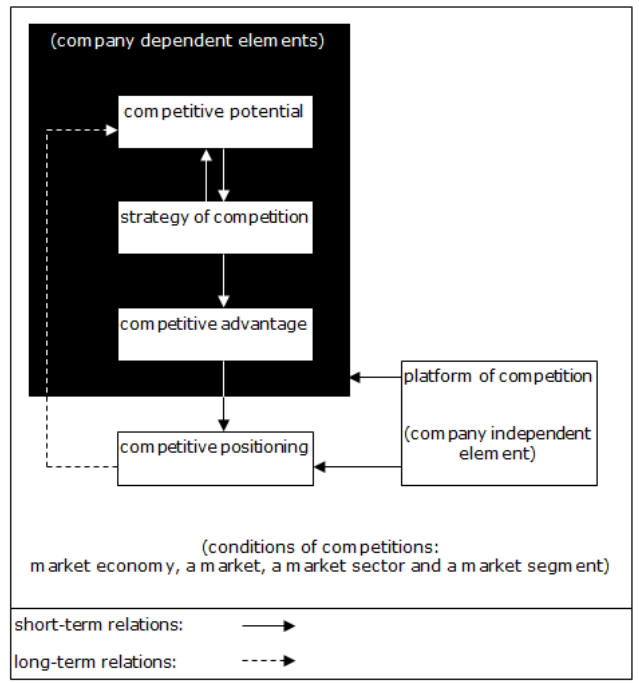

Fig. 1. The Company Competitiveness Integrated Model

Source: [5] 
The competitive position of an organization is described as the position of an organization compared to its competitors in the same market or industry. Knowledge of competitive positions allows the enterprises to make tactical plans to maintain or improve their current positions or possibly withdraw from the market. Therefore, the knowledge of the competitive position of an organization and its rivals is critical. Since rivals are defined as organizations that are able to obstruct a company's market goals, and important moderators of a company's performance. They are considered as the most crutial elements in competitive strategies [8].

Competitive advantage is whatever value a business provides that motivates its customers (or end users) to purchase its products or services rather than those of its competitors and that poses impediments to imitation by actual or potential direct competitors. With a clearer understanding of competitive advantage, more systematic methods for gathering customer and competitor information, and careful analysis of the changes in both, businesses can do better job assessing, building, communicating, maintaining and enhancing competitive advantage [9].

Generating superior financial performance by exploiting sources of sustainable competitive advantage is an everlasting quest for commercial enterprises around the world [10].

To the extent that superior performance is not absolutely a function of competitive advantage, all firms (both these that have developed competitive advantage and these that have not) seem to have an opportunity to achieve superior performance. Practicing managers ought to bear in mind that even if they have ben able to develop competitive advantage, their firm maight underperform in case the benefit from the competitive advantage is lower compared to the cost incurred to develop it [11].

It should be mentioned, that quality as an element of competitive advantage next to the cost advantage seems to be the basic source of its construction [12].

The marketing mix comprises of four decisions which should be considered before launching a product. Firms ought to plan targeted approach on these four different components and they are product, price, and place \& promotion. All the four variables are very helpfull the the firm in formulating strategic decisions necessary for competitive advantage [13].

Research on the impact of competitive advantage on the effectiveness of companies has been conducted for many years [14]. In many cases, the competitive advantage achieved is identified with the financial results of enterprises $[15,16]$.

\section{Methodology of the research}

The research was conducted in a period of 09.01.2020-09.04.2020 by the survey implemented in Sensorium24.com. The survey contained 45 questions of the Company Competitiveness Barometer [17]. 8 of them concerned a competitive advantage and 6 of them concerned a competitive positioning. Competitive advantage question were grouped in two according to four elements of marketing-mix which was a classic base of a competitive advantage. The description and literature study which are presented above show strength relationship between marketing mix and competitive advantage [18].

In the research 210 companies from Silesian Region took part from several different market sectors and different size, however, $89 \%$ of them were small and medium size. Companies were divided into 4 groups depending on the dominant source of a competitive advantage. There were 26 companies price oriented, 66 companies which used a place as a source of a competitive advantage, 72 companies focused in products as a competitive advantage and 46 companies using a promotion to create a competitive advantage. In the 
Section 4 there are results presented in percentage of a share of every type of a competitive advantage source.

\section{Results of the research}

The results of the research contains relations of four different competitive advantages based on different sources coming from a marketing-mix (a price, a place, a product and a promotion) and six indicators of a competitive positioning.

The first indicator of a competitive positioning is a level of a cash flow. Fig 2 presents the trajectory of this level depending on a source of a competitive advantage. The exact percentage of companies there are in Table 1. The most number companies which had a source as a promotion had high level of a cash flow $(45,65 \%)$. The companies using a place as a competitive advantage in $42,42 \%$ answered "very high". None of companies which used a product as a source had very low level of a cash flow, however, whose which used a price answered "very low" in 7,69\%.

\section{level of a cash flow}

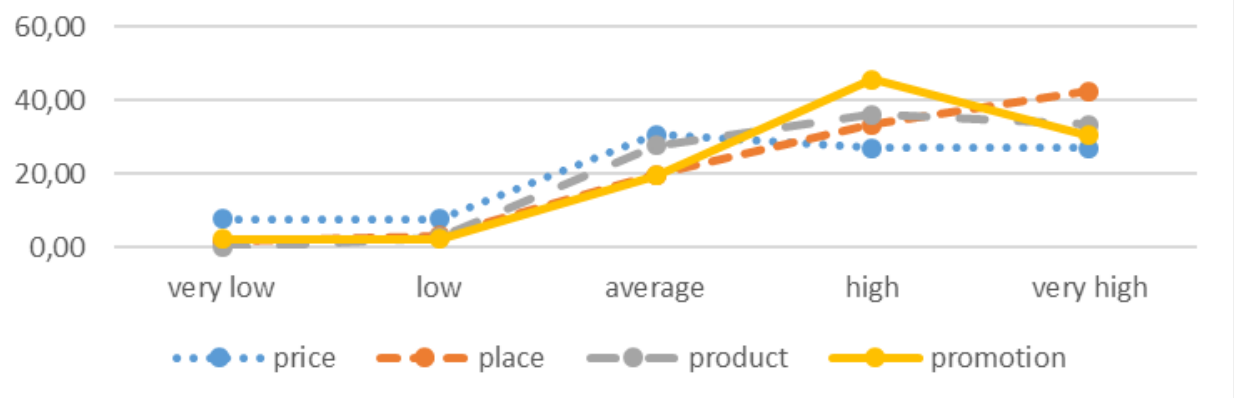

Fig .2. Trajectory of a level of a cash flow in function of a source of a competitive advantage

Table 3. Percentage of a level of a cash flow and a source of a competitive advantage relation

\begin{tabular}{|c|c|c|c|c|c|}
\hline \multirow{2}{*}{$\begin{array}{c}\text { source of a competitive } \\
\text { advantage }\end{array}$} & \multicolumn{5}{|c|}{ indicator of a competitive positioning } \\
\cline { 2 - 6 } & \multicolumn{5}{|c|}{ level of a cash flow } \\
\cline { 2 - 6 } & very low & low & average & high & very high \\
\hline price & 7,69 & 7,69 & 30,77 & 26,92 & 26,92 \\
\hline place & 1,52 & 3,03 & 19,70 & 33,33 & 42,42 \\
\hline product & 0,00 & 2,78 & 27,78 & 36,11 & 33,33 \\
\hline promotion & 2,17 & 2,17 & 19,57 & 45,65 & 30,43 \\
\hline
\end{tabular}

The second indicator of a competitive positioning is a level of external debts. Fig 3 presents the trajectory of this level depending on a source of a competitive advantage. The exact percentage of companies there are in Table 2. As it can be seen on the Fig 3, the highest numbers of answers $(54,35 \%$ and $53,03 \%)$ of "very low" level of debts gave companies using a competitive advantage based on a promotion and a place, respectively. What is really astonishing, none of a company had very high level of external debts, no matter which source of a competitive advantage they used. 


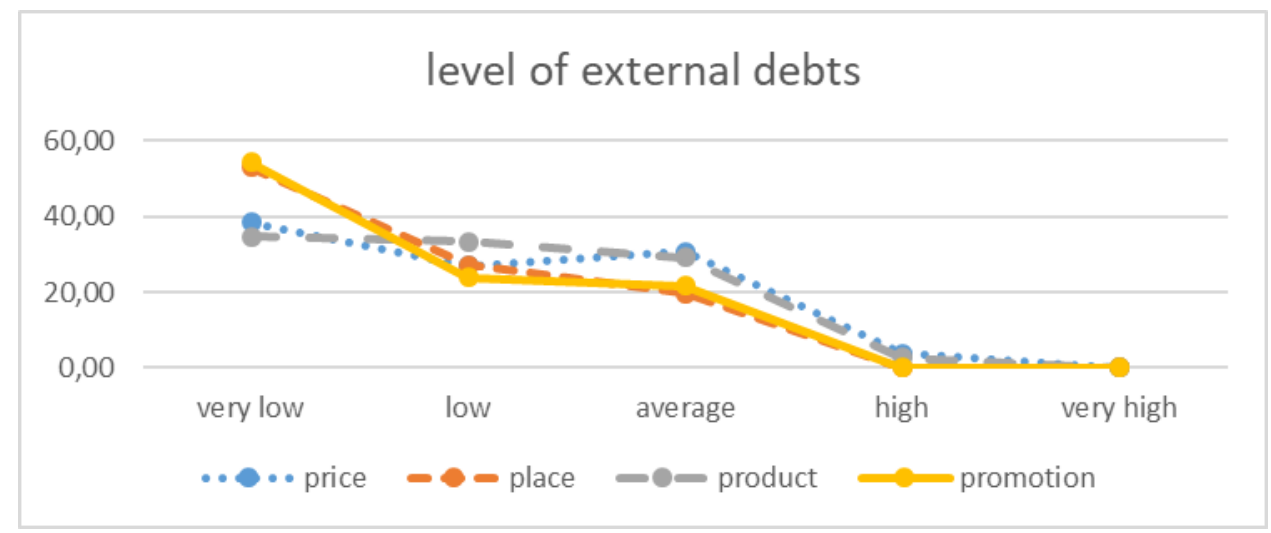

Fig .3. Trajectory of a level of external debts in function of a source of a competitive advantage

Table 2. Percentage of a level of external debts and a source of a competitive advantage relation

\begin{tabular}{|c|c|c|c|c|c|}
\hline \multirow{2}{*}{$\begin{array}{c}\text { source of a competitive } \\
\text { advantage }\end{array}$} & \multicolumn{5}{|c|}{ indicator of a competitive positioning } \\
\cline { 2 - 6 } & \multicolumn{5}{|c|}{ level of external debts } \\
\cline { 2 - 6 } & very low & low & average & high & very high \\
\hline price & 38,46 & 26,92 & 30,77 & 3,85 & 0,00 \\
\hline place & 53,03 & 27,27 & 19,70 & 0,00 & 0,00 \\
\hline product & 34,72 & 33,33 & 29,17 & 2,78 & 0,00 \\
\hline promotion & 54,35 & 23,91 & 21,74 & 0,00 & 0,00 \\
\hline
\end{tabular}

The next indicator of a competitive positioning is a level of market share. As it can be seen on the Fig 4 in Table 3, mostly all companies using different sources of their competitive advantages assessed their market shares as average without an impact of the source of a competitive advantage. This is quite interesting result which could tell us that the most of companies used adequate sources of their competitive advantages. However, there were $19,23 \%$ of companies which used a price as a source which noticed a very low market share. In the same time, $8,7 \%$ companies using a promotion claimed that they had a very high market share. So, on the one hand, companies can use a proper source of a company advantage. On the other hand, the source really influence on a market share.

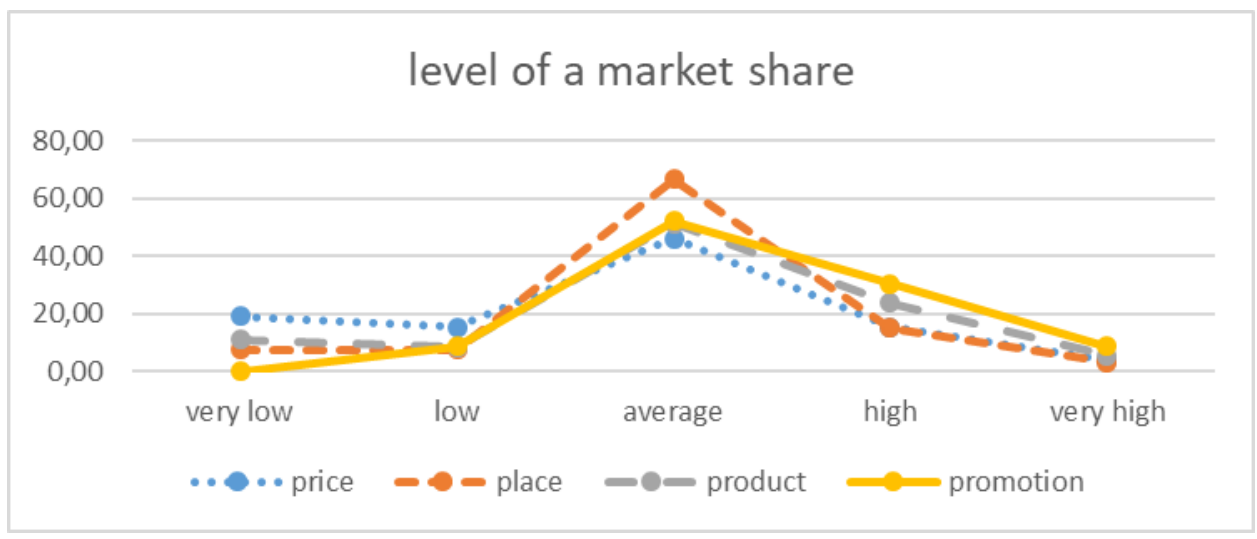

Fig .4. Trajectory of a level of a market share in function of a source of a competitive advantage 
Table 3. Percentage of a level of a market share and a source of a competitive advantage relation

\begin{tabular}{|c|c|c|c|c|c|}
\hline \multirow{2}{*}{$\begin{array}{c}\text { source of a competitive } \\
\text { advantage }\end{array}$} & \multicolumn{5}{|c|}{ indicator of a competitive positioning } \\
\cline { 2 - 6 } & \multicolumn{5}{|c|}{ level of a market share } \\
\cline { 2 - 6 } & very low & low & average & high & very high \\
\hline price & 19,23 & 15,38 & 46,15 & 15,38 & 3,85 \\
\hline place & 7,58 & 7,58 & 66,67 & 15,15 & 3,03 \\
\hline product & 11,11 & 8,33 & 51,39 & 23,61 & 5,56 \\
\hline promotion & 0,00 & 8,70 & 52,17 & 30,43 & 8,70 \\
\hline
\end{tabular}

The fourth indicator of a competitive positioning is a level of profitability. As it can be seen on the Fig 5 and in Table 4, the highest number of respondents $(54,55 \%)$ who used a place as a source of competitive advantage claimed that they achieved high profitability. Nearly the same number $(53,85 \%)$ used a source of a price. What is really interesting, there were very few companies which noticed very low profitability in any types of a competitive advantage. The biggest difference in profitability was among companies which had average profitability - only 19,23\% of "price" users and $45,83 \%$ of "product" users.

\section{level of profitability}

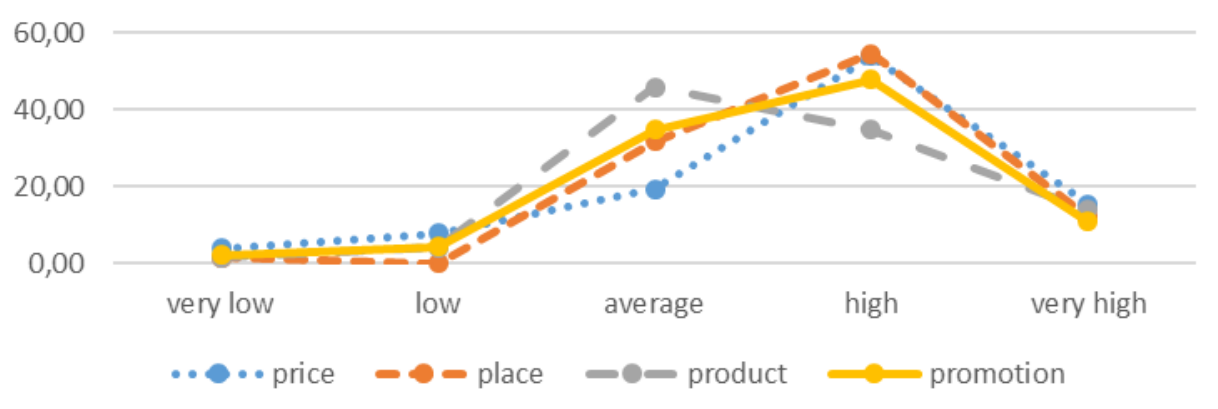

Fig .5. Trajectory of a level of profitability in function of a source of a competitive advantage

Table 4. Percentage of profitability and a source of a competitive advantage relation

\begin{tabular}{|c|c|c|c|c|c|}
\hline \multirow{2}{*}{$\begin{array}{c}\text { source of a competitive } \\
\text { advantage }\end{array}$} & \multicolumn{5}{|c|}{ indicator of a competitive positioning } \\
\cline { 2 - 6 } & \multicolumn{5}{|c|}{ level of profitability } \\
\cline { 2 - 6 } & very low & low & average & high & very high \\
\hline price & 3,85 & 7,69 & 19,23 & 53,85 & 15,38 \\
\hline place & 1,52 & 0,00 & 31,82 & 54,55 & 12,12 \\
\hline product & 1,39 & 4,17 & 45,83 & 34,72 & 13,89 \\
\hline promotion & 2,17 & 4,35 & 34,78 & 47,83 & 10,87 \\
\hline
\end{tabular}

The next indicator of a competitive positioning is a level of sale increase measured year by year. As it can be seen on the Fig 6 and in Table 5, most of companies said that they increased their sale on average. However, the companies using a product as a source of a competitive advantage were in $55,56 \%$, and there were only $39,13 \%$ of companies used a promotion. What is astonishing, a quite low number of companies had very low and low sale increase - no matter which source they used to build their competitive advantage. However, the highest number of companies which had very high increase used a promotion as a source $(15,22 \%)$. 


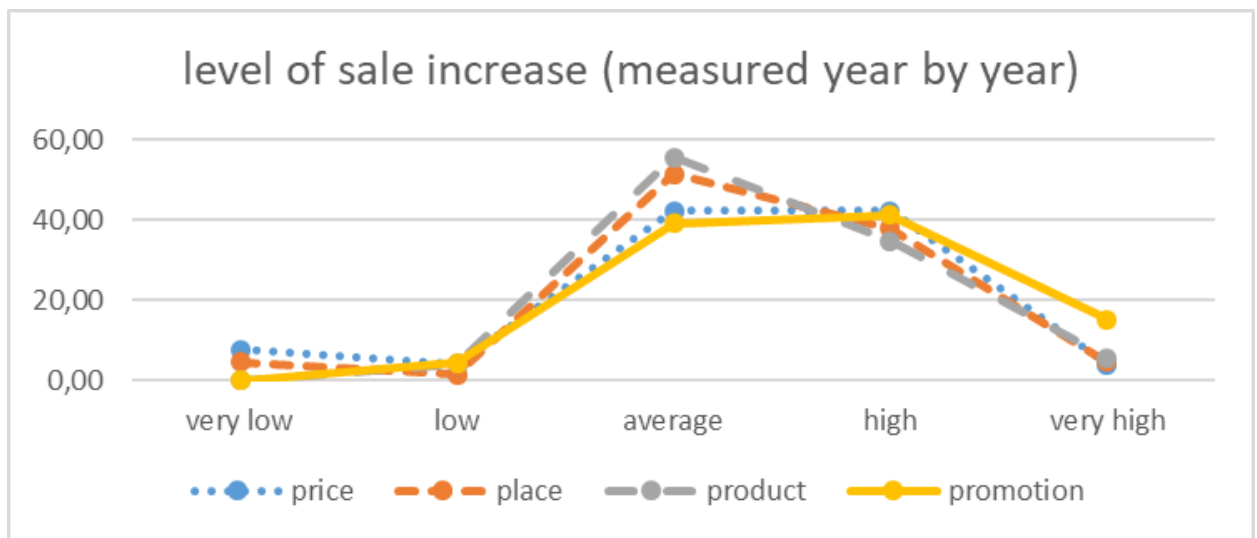

Fig .6. Trajectory of a level of profitability in function of a source of a competitive advantage

Table 5. Percentage of profitability and a source of a competitive advantage relation

\begin{tabular}{|c|c|c|c|c|c|}
\hline \multirow{2}{*}{$\begin{array}{c}\text { source of a competitive } \\
\text { advantage }\end{array}$} & \multicolumn{5}{|c|}{ indicator of a competitive positioning } \\
\cline { 2 - 6 } & \multicolumn{4}{|c|}{ level of sale increase (measured year by year) } \\
\cline { 2 - 6 } & very low & low & average & high & very high \\
\hline price & 7,69 & 3,85 & 42,31 & 42,31 & 3,85 \\
\hline place & 4,55 & 1,52 & 51,52 & 37,88 & 4,55 \\
\hline product & 0,00 & 4,17 & 55,56 & 34,72 & 5,56 \\
\hline promotion & 0,00 & 4,35 & 39,13 & 41,30 & 15,22 \\
\hline
\end{tabular}

The last indicator of a competitive positioning is equity of profitability. As it can be seen on the Fig 7 and in Table 6, none of the companies answered that this indicator is very low. Also very few had this indicator at a low level. It is possible to claim that this indicator did not depend much on a source of a competitive advantage - most of answers were similar.

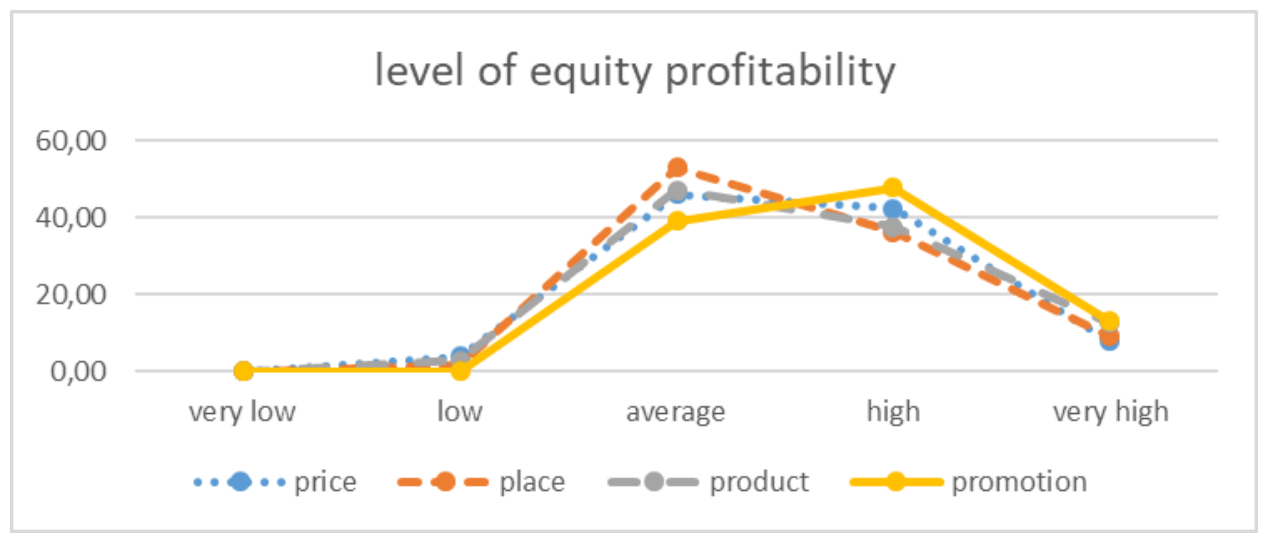

Fig .7. Trajectory of a level of profitability in function of a source of a competitive advantage

Table 6. Percentage of profitability and a source of a competitive advantage relation

\begin{tabular}{|c|c|c|c|c|c|}
\hline \multirow{2}{*}{$\begin{array}{c}\text { source of a competitive } \\
\text { advantage }\end{array}$} & \multicolumn{5}{|c|}{ indicator of a competitive positioning } \\
\cline { 2 - 6 } & \multicolumn{5}{|c|}{ level of equity profitability } \\
\cline { 2 - 6 } & very low & low & average & high & very high \\
\hline price & 0,00 & 3,85 & 46,15 & 42,31 & 7,69 \\
\hline place & 0,00 & 1,52 & 53,03 & 36,36 & 9,09 \\
\hline product & 0,00 & 2,78 & 47,22 & 37,50 & 12,50 \\
\hline
\end{tabular}


promotion 0,00 0,00 39,13 47,83 13,04

\section{Conclusions}

The presented analysis of empirical research results shows the impact of individual competitive advantages on the competitive position, which was expressed through the financial indicators of the surveyed enterprises.

The analysis indicates the need for further search for sources of competitive advantage and research in the field of measuring the effects of achieved competitive advantage. Due to the cyclically conducted research using the Company Competitive Integrated Model, subsequent studies will be an opportunity to develop research in this area in the future. As a result, it will be possible to continue research in an in-depth range from those presented in this article.

\section{References}

[1] S. Farhikhteh, A. Kazemi, A. Shahin, A., M.M. Shafiee, How competitiveness factors propel SMEs to achieve competitive advantage? Competitiveness Review: An International Business Journal 1, 13-21 (2020)

[2] M. Kharub, R. Sharma, An integrated structural model of QMPs, QMS and firm's performance for competitive positioning in MSMEs. Total Quality Management \& Business Excellence 31, 3-4, 312-241 (2020)

[3] E. Akben-Selcuk, Factors affecting firm competitiveness: Evidence from an emerging market. International Journal of Financial Studies 4, 2, 1-10 (2016)

[4] O. Flak, G. Głód, G., Concept Research of the Competitiveness of Enterprises in Selected Countries in the European Union. S. Majtan (eds.) Aktuálne problémy podnikovej sféry. Bratislava, Vydavatel'stvo EKONÓM, 86-92, (2014)

[5] O. Flak, G. Głód, Konkurencyjni przetrwają. Difin, Warszawa (2012)

[6] J.W. Bossak, W. Bieńkowski, W., Międzynarodowa zdolność konkurencyjna kraju $i$ przedsiębiorstw. Wyzwania dla Polski na progu XXI wieku. Wyd. SGH, Warszawa (2004)

[7] O. Flak, G. Głód, Konkurencyjność przedsiębiorstwa. Pojęcia, definicje, modele. Cz. 1. Wydawnictwo Akademii Ekonomicznej w Katowicach, Katowice (2009)

[8] V.L. Dang, G.T. Yeo, A competitive strategic position analysis of major container ports in Southeast Asia. The Asian Journal of Shipping and Logistics 33, 1, 19-25 (2017)

[9] H.K. Christensen, Defining customer value as the driver of competitive advantage. Strategy \& Leadership 38, 20-25 (2010)

[10] M. Holm, V. Kumar, T. Plenborg, An investigation of customer accounting systems as a source of sustainable competitive advantage. Advances in accounting 32, 18-30 (2016)

[11] C. Sigalas, V.M. Papadakis, Empirical investigation of relationship patterns between competitive advantage and superior performance. Journal of Strategy and Management 11, 1, 1-32 (2018)

[12] I.A. Elshaer, M.M. Augustyn, Direct effects of quality management on competitive advantage. International Journal of Quality \& Reliability Management 29, 3, 265-283 (2016) 
[13] M. Singh, Marketing mix of 4P's for competitive advantage. IOSR Journal of Business and Management 3, 6, 40-45 (2012)

[14] H. Ma, Competitive advantage and firm performance. Competitiveness Review 10, 2 , $15-32(2000)$

[15] S. Cantele, A. Zardini, Is sustainability a competitive advantage for small businesses? An empirical analysis of possible mediators in the sustainability-financial performance relationship. Journal of Cleaner Production 182, 166-176 (2018)

[16] A. Agus, R.M. Sagir, The structural relationships between total quality management, competitive advantage and bottom line financial performance: An empirical study of Malaysian manufacturing companies. Total Quality Management 12, 7-8, 1018-1024 (2001)

[17] O. Flak, A Method of Estimating the Determinant of Enterprise Competetiveness. A. Nalepka, A. Ujwary (eds.), Business and Non-profit Organizations Fading Increased Competition and Growing Customers' Demands, Wyższa Szkoła Biznesu, Nowy Sącz, 113-128 (2014)

[18] E. Chumaidiyah, The marketing mix strategy in influence to the competitive advantage. Proceedings of the 2014 International Conference on Industrial Engineering and Operations Management 7, 9, 818-826 (2014) 